5. Мендель заявила, що в Україні є «українська» російська мова. Режим доступу: https://www.unian.ua/society/movne-pitannya-mendelzayavila-shcho-v-ukrajini-ye-ukrajinska-rosiyska-mova-novini-ukrajini-11 376679.html?utm_source=social\&utm_medium=share\&utm_campaign=site\& fbclid=IwAR2QfMif_t19F9ev4lTAsbqtX47tvcfRnazhkBnKndHyv5_lmXbeiv H5vNA, (дата звернення 04.04.21).

6. «Ми повинні вітати розвиток нашої російської мови, якою розмовляють мільйони українців, i давати ій можливість вільно розвиватися». Режим доступу: https://www.radiosvoboda.org/a/newsavakov-rosiyska-mova-rozvytok/31178355.html (дата звернення 30.03.21).

7. «Не думаю нею вільно»: Зеленський висловився про українську мову. Режим доступу: https://intermarium.com.ua/ne-dumayu-neyu-vilnozelenskyj-vyslovyvsya-pro-ukrayinsku-movu/_(дата звернення 10.03.20).

8. «Не треба утискувати!». Режим доступу: https:// www.obozrevatel.com/ukr/politics/ne-treba-tisnuti-zelenskij-zhorstkozastupivsya-za-rosijsku-movu.htm (дата звернення 22.03.2019).

9. Радевич-Винницький Ярослав, Іванишин Василь. Мова і нація. Львів: Апріорі, 2012. 210 с.

10. Фаріон Ірина. Законодавче поле української мови: колоніяльна, ліберально-гібридна і національна мовні моделі (1989-2019 рр.). Украӥнська реальність крізь призму терміна. Львів: Видавництво Львівської політехніки, 2019. С. 47-93.

DOI https://doi.org/10.30525/978-9934-26-073-5-2-48

\title{
ОТРАЖЕНИЕ КАТЕГОРИИ АДРЕСАНТА В РЕЧЕВОМ СОБЫТИИ МАССМЕДИЙНОГО ПОЛИТИЧЕСКОГО ДИСКУРСА УКРАИНЫ
}

\author{
Филатенко И. А. \\ кандидат филологических наук, \\ доиент кафедры соииально-гуманитарных дисииплин \\ Киевского медицинского университета \\ г. Киев, Украина
}

Наблюдения авторитетных исследователей языка [5], [8], указывающих на существование особого типа события (далее - С.), которое нашло отражение в тексте («текстовое событие» в терминологии В. 3. Демьянкова [5]), а также размышления философов, социологов, 
политологов о специфике С. в условиях современного информационного общества, фиксирующих новое явление, - медиасобытие [9], свидетельствуют о необходимости лингвистического изучения этого феномена. Полагаем, что его природа отлична от онтологической. Репрезентованное в массмедийной политической коммуникации, оно представляет собой явление особого порядка. Таким образом, событие реального мира (далее также - С.), преломленное сквозь призму дискурса, в частности - средств массовой информации, нашедшее вербальную репрезентацию в его коммуникативном пространстве, предстаёт в другой ипостаси, приобретает новые характеристики. Такое событие называем событием речевым (далее также - РС) [10], [11] .

Описание РС, явленного в политическом дискурсе масс-медиа, предполагает выявление признаков, определяющих его специфику. Наряду с конститутивными свойствами, объективно определяющими сущность вещи, речевое событие обнаруживает и консекутивные, то есть следующие из других. К числу первых относятся обязательное наличие адресанта (субъекта) РС, а также специфическая локализация последнего (массмедийная, политическая сферы жизни общества, дискурсивное пространство). Консекутивными свойствами РС считаем принципиальную конструируемость, сценарность, контролируемость и пр. Остановимся подробнее на последнем.

Событие как онтологическая категория внеположно воле человека, который, однако, может ожидать, планировать, но далеко не всегда в состоянии обеспечить или предотвратить его наступление. Оно самопроизвольно. Люди не в состоянии полностью предугадать вероятный результат С. Человек, даже будучи инициатором события, всё же его не вершит [1]. РС в массмедийной политической коммуникации обнаруживает иное свойство. Адресант, либо агентивный субъект речевого события прилагает сознательные усилия к его осуществлению, руководствуясь при этом определенными мотивами, побуждающими к действию:

1. Инициирует создание РС. Такой субъект проявляет волю, намерение, желание, то есть принимает соответствующее решение и демонстрирует устремление совершить действие - вербально репрезентировать С. в средствах массовой информации. Это находит своё выражение в отборе определенного события из ряда других, произошедших, по утверждению адресанта, в действительности: будет ли включено С. в «повестку дня» (заключено в дискурсивные рамки описания реальности), а значит, получит ли оно вербальную репрезентацию в масс-медиа, зависит от агентивного субъекта. 
2. Реализует свои намерения, то есть вербализует выбранное событие в СМИ. При осуществлении задуманного агентивный субъект преследует разные цели, может выражать различные точки зрения, но в целом стремится оказать воздействие на адресата, представив «правильную версию» С. Для этого он использует оптимальные, по его мнению, средства (языковые/речевые, когнитивные, прагматические), выбор которых так же, как и выбор С., зависит от него.

3. Приходит к определенному прогнозируемому результату своих усилий, под которым в целом понимаем вербально репрезентированное в масс-медиа С., по утверждению адресанта, произошедшее в действительности. То есть событие речевое. Каким оно явилось - зависело от агентивного субъекта.

Соблюдение перечисленных условий адресантом (агентивным субъектом) при реализации разных аспектов действий предполагает, что он осуществляет контроль над ними [6]. (Слово контроль используем в значении, заимствованном из английского языка и развивающемся в настоящий период, - управление, руководство, власть [3].)

Очевидно, что контроль агентивного субъекта РС является не только интенсиональнылм (принятие решения, выбор схемы деятельности, т.е. ментальные операции), поскольку изменения в окружающем мире происходят не потому, что некто принял определенное решение. Адресант речевого события затрачивает собственные усилия, расходует энергию (производит «действие по внутреннему импульсу», «решающий вклад в действие» [4, с. 98]), что приводит к искомому результату созданию РС. В таком ракурсе речь идет и о контроле на денотативном срезе. (О терминах интенсиональный / денотативный контроль см.: [7].) Следовательно, адресант, созидая РС, управляет этим процессом и приходит к определенному результату, и в этом смысле речевое событие, в отличие от С. как онтологической категории, контролируемо. Полагаем, что использование относительно РС термина «контролируемость», введенного Т. В. Булыгиной при классификации семантических типов предикатов [2], вполне оправдано, поскольку в целом контролируемыми называют явления, при которых именно субъект определяет, будет или не будет иметь место некое положение вещей (С. в широком смысле).

По справедливому замечанию Г. И. Кустовой [7], принципиальной особенностью контроля является то, что он имеет сферу действия, и непосредственно субъект контролирует только свои усилия, направленные на то, чтобы вызвать изменения. В силу того, что между затрачиваемыми усилиями и внешними изменениями существует определенная связь (причина - следствие), субъект, по мнению 
исследователя, контролирует эти изменения и, соответственно, достижение результата. Иными словами, РС контролируемо агентивным субъектом в координатах инициирование - достижение результата (в сфере приложения его усилий). Безусловно, контролировать «жизнь» РС в массмедийном, политическом, дискурсивном пространстве, его воздействие на адресата и пр. он не в состоянии, но возникнет ли речевое событие и каким оно явится - решает именно адресант.

\section{Литература:}

1. Арутюнова Н. Д. Предложение и производные от него значения. Язык и мир человека. Н. Д. Арутюнова М. 1999.

2. Булыгина Т. В. Контролируемые / неконтролируемые положения вещей. Семантические типь предикатов: монография / А.Г. Елисеева, О.Н. Селиверстова, Т.В. Булыгина. М. 1982. С. 7-85.

3. Васильев А. Д. Кто и как может контролировать ситуацию? Лингвистический ежегодник Сибири. Красноярск, 1999. С. 8-18.

4. Григорьян Е. Л. Действие и деятель. Логический анализ языка. Модели действия: монография / Н.Д. Арутюнова, Е.Л. Григорьян, Т.В. Булыгина. М.: Наука, 1992. - С. 96-102.

5. Демьянков В. 3. «Событие» в семантике, прагматике и в координатах интерпретации текста. Известия АН СССР. Серия литературы и языка. 1983. Т. 42. № 4. С. 320-329.

6. Ким И. Е. Контролируемость действия: сущность и структура. Лингвистический ежегодник Сибири. Красноярск, 1999. С. 19-31.

7. Кустова Г. И. Некоторые проблемы анализа действий в терминах контроля. Логический анализ языка. Модели действия: Монография / Н.Д. Арутюнова, Е.Л. Григорьян, Т.В. Булыгина. М.: Наука, 1992. - С. 145-150.

8. Леонтьев А. А. Психолингвистические особенности языка СМИ. Язык СМИ как объект междисииплинарного исследования: труды: монография. М.Н. Володина, В.З. Демьянков, А.А. Леонтьев. М. 2003. C. 66-88.

9. Филатенко И. А. Политическое событие в координатах социологии и политологии. Молодой ученый. М., 2012. №11 (46). С. 243 -245.

10. Филатенко И. А. Конститутивные признаки речевого события в политическом дискурсе масс-медиа. Мовні $i$ концептуальні картини світу. К. 2012. Вип. 43. Ч. С. 192-199.

11. Филатенко И. А.Речевое событие в политическом дискурсе масс-медиа Украины: параметры классификации. Наукові записки Ніжинського державного університету ім. М.Гоголя. Серія «Філологічні науки». Ніжин. 2014. Кн. 2. - С. 257-261. 